\title{
Katarzyna Chmielewska
}

Instytut Badań Literackich PAN

https://orcid.org/0000-0003-4095-2834

katarzyna.chmielewska@ibl.waw.pl

\section{Pamięć wielokierunkowa i agoniczna a polityka pamięci}

\begin{abstract}
Streszczenie
Autorka rekonstruuje i poddaje krytycznej analizie współczesne modele społecznej i kulturowej pamięci o Zagładzie oraz rozważa wynikające z nich konsekwencje dla rozumienia polityki historycznej. Przedmiotem opisu są dominujące obecnie kierunki memory studies, nawiązujące do Chantal Mouffe (koncepcja agonu) oraz głębiej - Michaiła Bachtina (polifoniczność i dialogiczność), a więc koncepcje pamięci agonicznej i wielokierunkowej. W kontrze do tych koncepcji autorka rozwija wątki niedoceniane w dotychczasowych badaniach: zagadnienia społecznego (klasowego) uwarunkowania pamięci, przemocy symbolicznej i prawomocności, które kształtują pamięć kulturową i przedstawienia przeszłości.
\end{abstract}

\section{Słowa kluczowe}

pamięć wielokierunkowa, pamięć agoniczna, polityka pamięci

\begin{abstract}
The author reconstructs and critically analyzes contemporary models of social and cultural memory of the Holocaust and considers their consequences for the understanding of politics of memory. The subject of consideration are the dominant trends in memory studies, referring to Chantal Mouffe (the concept of agon) and, more deeply, to Mikhail Bakhtin (polyphony and dialogicity), i.e. the concepts of agonic and multidirectional memory. As a counterpoint to these concepts, the author develops threads underestimated in previous research: the issues of the social (class) condition of memory, symbolic violence and legitimacy, which shape cultural memory and representations of the past.
\end{abstract}

\section{Key words}

multidirectional memory, agonic memory, politics of memory

Badaniom nad Zagładą można postawić zarzut, że jest to dyscyplina bez jednorodnej metodologii i spójnego paradygmatu, zintegrowana jedynie na mocy wspólnej dziedziny zainteresowań: zagłady Żydów. Istotnie, trzeba by raczej mówić o obszarze badań niż o dyscyplinie, gdyż studia te odznaczają się różnorodnością podejść teoretycznych i perspektyw naukowych. Obszar ten zgłębia 
akademicka nauka historii, a ponadto socjologia, psychologia, antropologia, literaturoznawstwo, filozofia, psychoanaliza, filmoznawstwo, memory studies i inne. Warto przy tym zauważyć, że nawet przedmiot badań budzi pewne wątpliwości, nie jest ściśle odgraniczony i jednoznaczny. Dyskusyjne są ramy czasowe i nie są to spory akademickie, formalne, gdyż w znacznej mierze rzutują na rozumienie Zagłady, tezy i użyte kategorie. Zależnie od tego, jaki moment uznajemy za początkowy, interpretacja Zagłady się zmienia. Jeśli na przykład za początek Zagłady uznajemy konferencję w Wannsee (20 stycznia 1942), badania skupią się na pewnym etapie, czyli na skrystalizowaniu projektu masowego, planowego, „przemysłowego” mordowania w obozach, określonego mianem „ostatecznego rozwiązania". Jeśli natomiast przesuniemy początek na lata wcześniejsze, jeszcze przed drugą wojną światową, dostrzeżemy kontekst polityczny, społeczny i kulturowy antysemityzmu; badamy wówczas zazwyczaj długotrwałe procesy w obrębie nowoczesnych społeczeństw, które Zagładę umożliwiły i do niej doprowadziły. Podobnie jest z momentem końcowym - jeśli za kres Zagłady, a tym samym zainteresowań badawczych, uznajemy nie rok 1945, ale włączamy również lata późniejsze, przyznajemy tym samym, że lokalne warunki, wyobrażenia społeczne i zaangażowanie w Zagładę ( $w$ tym wypadku społeczeństwa polskiego) są istotnym jej elementem i Zagłady nie możemy ograniczyć do niemieckiego sprawstwa.

Rozmaite wyznaczanie granic czasowych opisywanych zjawisk nie wyczerpuje wątpliwości związanych z obszarem badań. Zasadnie można zapytać, czy do pola badań nad Zagładą należy również Porajmos, czyli zagłada Romów i Sinti. Utrwalona praktyka badawcza zwykła bowiem traktować Szoa i Porajmos rozłącznie, najczęściej zajmują się nimi inni badacze, obie dziedziny są też rozdzielone na poziomie instytucjonalnym, choć wiele zyskałyby przynajmniej na badaniach porównawczych. Wątpliwości te nie przekreślają jednak wyrazistego wyodrębnienia pola badań.

W niniejszym szkicu chciałabym zwrócić uwagę na memory studies i ich względnie nowe, popularne ujęcia tematu Zagłady oraz pamięci traumatycznej. Założenia i kierunki badań, które chciałabym przedstawić i poddać pod dyskusję, odnoszą się do pamięci kulturowej albo komunikacyjnej, tj. takiej, która utrwala się w wytworach kultury albo jest przedmiotem żywej komunikacji społecznej. Kanoniczną postać tym kategoriom nadali klasycy memory studies, Pierre Nora ${ }^{1}$ oraz Aleida i Jan Assmannowie ${ }^{2}$, ale znaleźć je można systematycz-

${ }^{1}$ Pierre Nora, Between Memory and History: Les Lieux de Mémoire, „Representations” 1989, t. 26, s. 7-25, doi:10.1525/rep.1989.26.1.99p0274v.

${ }^{2}$ Aleida Assmann, Jan Assmann, Schrift und Gedächtnis: Beiträge zur Archäologie der literarischen Kommunikation. München: Fink, 1987; Memory and Political Change, red. Aleida Assmann, Linda Shortt, London: Palgrave Macmillan, 2011; Aleida Assmann, Memory, Individual and Collective [w:] The Oxford Handbook of Contextual Political Analysis, red. Robert E. Goodin, Charles Tilly, Oxford: Oxford University Press, 2006. 
nie opracowane w innych tekstach, np. Astrid Erll ${ }^{3}$ i Haralda Walzera ${ }^{4}$. Badacze i badaczki pamięci analizują dokumenty historyczne, teksty kultury, instytucje, happeningi, obiekty kultury materialnej, wydarzenia, wspomnienia, pamiętniki, dzienniki, listy, teksty publicystyczne, artykuły prasowe, wystawy, teksty literackie, dokumenty artystyczne, archiwa; rekonstruują również dyskursy społeczne, wyodrębniają dyskursy dominujące i mniejszościowe. Trzeba zaznaczyć, że dla memory studies Zagłada stanowi obszar szczególny - nie tylko jako temat rozważań, lecz także jako zadanie metodologiczne, obszar, który domaga się specjalnych narzędzi. Ze względu na etyczne wezwanie Zagłady powstały takie kategorie, jak świadek moralny ${ }^{5}$, pamięć traumatyczna, wspólnoty pamięci ${ }^{6}$, stanowiące kanon pojęciowy pamięcioznawstwa.

Relacje między nauką historii a jej młodszą siostrą, czyli memory studies, bywają trudne i niejednoznaczne. $Z$ jednej strony wspólne są im inspiracje narratologiczne $^{7}$ (Hayden White), bliskie są im oral history ${ }^{8}$ i history from below ${ }^{9}$, a historia mówiona zbliża się do badań nad pamięcią komunikacyjną. Z drugiej zaś historycy czasem z trudem dostrzegają dyscyplinarną różnicę między obiema tymi gałęziami refleksji o przeszłości, a niekiedy z jeszcze większym trudem samo istnienie takiej dziedziny jak memory studies. Niekiedy zaś zgłaszają wątpliwości ${ }^{10}$ wobec nich jako dyscypliny słabo ukształtowanej, zajmującej się czymś tak mało policzalnym jak pamięć społeczna i kulturowa, bez zagłębiania się w dane ilościowe, pochodzące z badania opinii publicznej. W gruncie rzeczy można ten

${ }^{3}$ Cultural Memory Studies. An International and Interdisciplinary Handbook, red. Astrid Erll, Ansgar Nünning, Berlin: De Gruyter, 2008.

${ }^{4}$ Harald Welzer, Das kommunikative Gedächtnis. Eine Theorie der Erinnerung, München: Beck, 2011; Harald Welzer, Sabine Moller, Karoline Tschuggnall, „Dziadek nie był nazista”. Narodowy socjalizm i Holokaust w pamięci rodzinnej, tłum. Paweł Masłowski [w:] Pamięć zbiorowa i kulturowa. Współczesna perspektywa niemiecka, red. Magdalena Saryusz-Wolska, Kraków: Universitas, 2009, s. 351-410.

${ }^{5}$ Aleida Assmann, Vier Grundtypen der Zeugenschaft [w:] Zeugenschaft des Holocaust. Zwischen Trauma, Tradierung und Ermittlung, red. Michael Elm, Gottfried Kößler, Frankfurt am Main-New York: Campus, 2007, s. 33-51.

${ }^{6}$ Więcej na ten temat tych kategorii: Lech M. Nijakowski, Polska polityka pamięci. Esej socjologiczny. Warszawa: Wydawnictwa Akademickie i Profesjonalne, 2008.

${ }^{7}$ Frank Ankersmith, Historical Representation, Stanford, CA: Stanford University Press 2001; idem, Political Representation, Stanford, CA: Stanford University Press 2002.

${ }^{8}$ History of Oral History: Foundations and Methodology, red. Thomas L. Charlton, Lois E. Myers, Rebecca Sharpless, Lanham: Alta Mira Press, 2007.

${ }^{9}$ Edwin P. Thompson, History from Below, „Times Literary Supplement”, 7 IV 1966, s. 279-280.

${ }^{10}$ Więcej na ten temat por. Pamięć i polityka historyczna. Doświadczenia Polski i jej sq̨siadów, red. Sławomir M. Nowinowski, Jan Pomorski, Rafał Stobiecki, Łódź: Wydawnictwo Naukowe Ibidem, 2008; Historyk wobec źródeł. Historiografia klasyczna i nowe propozycje metodologiczne, red. Joanna Kolbuszewska, Rafał Stobiecki, Łódź-Kurowice: Wydawnictwo Naukowe Ibidem, 2010; Rafał Stobiecki, Historycy polscy wobec wyzwań XX wieku, Poznań: Wydawnictwo Nauka i Innowacje, 2014; Historia - dziś: teoretyczne problemy wiedzy o przeszłości, red. Ewa Domańska, Rafał Stobiecki, Tomasz Wiślicz, Kraków: Universitas, 2014. 
typ argumentacji sprowadzić do zarzutu o nieprzestrzeganie standardów pozytywizmu naukowego, wyrażane $\mathrm{w}$ formie troski o warsztat naukowy (lub raczej brak warsztatu), co samo w sobie brzmi anachronicznie z perspektywy współczesnej historiografii, daje jednak asumpt do refleksji metodologicznej i rozwoju zarówno studiom nad pamięcią, jak i historii akademickiej również w Polsce.

Coraz częściej bowiem teksty polskich badaczek i badaczy obu dyscyplin są głosem w sporach metodologicznych i teoretycznych, zarysowują nowe i przesuwają stare linie podziału oraz zawierają nowe rozstrzygnięcia teoretyczne, co prowadzi do większego zróżnicowania krajobrazu badawczego, ale zmusza zarazem do głębszej refleksji nad kategoriami używanymi w badaniach nad Zagładą, do odpowiedzi, czym jest pamięć, jakie są jej modele i jakie wyobrażenia społeczne mają dla nich charakter decydujący. Przykładem połączenia historiografii oraz badań antropologicznych i socjologicznych, niezwykle udanego opisu gęstego jest praca Joanny Tokarskiej-Bakir Pod klątwą. Społeczny portret pogro$m u$ kieleckiego ${ }^{11}$. Praca polskiej badaczki spełnia nie tylko założenia najbardziej skrupulatnych badań nauki historii, lecz łączy metody tradycyjne z mikrohistorią, historią społeczną ${ }^{12}$, analizą dyskursu, zbliża się do badań nad pamięcią ${ }^{13}$. Zupełnie innym przykładem będą teksty Romy Sendyki - stricte z obszaru memory studies, i jej kategoria nie-miejsca pamięci ${ }^{14}$, opisująca miejsca nieupamiętnione, których pamięć przetrwała jednak $\mathrm{w}$ przekazie międzypokoleniowym, czasem niejawnym, sprowokowanym; ustalenia historyczne są tu wyzwaniem, punktem konfrontacji dla pracy pamięcioznawcy. Przykładem inspirującego połączenia dyskursów są też rozprawy teoretyczne i prace historyczne nad Zagładą Ewy Domańskiej ${ }^{15}$, badaczki i propagatorki dorobku Haydena White'a, łączącej perspektywy antyantropologiczne z narratologią. To oczywiście tylko wybrane przykłady ciekawszych prób badawczych wokół Zagłady, włączających się w dyskusje nad paradygmatem tych badań.

\section{I}

Za jedne z najistotniejszych nurtów w badaniach nad pamięcią traumatyczną uznaje się dziś kierunki silnie inspirowane myślą Michaiła Bachtina ${ }^{16}$, a zwłasz-

${ }^{11}$ Joanna Tokarska-Bakir, Pod klątwq. Społeczny obraz pogromu kieleckiego, t. 1-2, Warszawa: Czarna Owca, 2018.

${ }^{12}$ Prace Joanny Tokarskiej-Bakir można wskazać jako pionierskie na gruncie polskich badań nad pamięcią klasową w kontekście Zagłady.

${ }^{13}$ Inne prace autorki można wprost zaliczyć do tej dyscypliny.

${ }^{14}$ Roma Sendyka, Pryzma - zrozumieć nie-miejsca pamięci (non-lieux de mémoire), „Teksty Drugie" 2013, nr 1/2, s. 323-344.

${ }^{15}$ Ewa Domańska, Nekros. Wprowadzenie do ontologii martwego ciała, Warszawa: Wydawnictwo Naukowe PWN, 2017; eadem, Historia egzystencjalna. Krytyczne studium narratywizmu i humanistyki zaangażowanej, Warszawa: Wydawnictwo Naukowe PWN, 2012.

${ }^{16}$ Michaił Bachtin, Problemy poetyki Dostojewskiego, tłum. Natalia Modzelewska, Warszawa: PIW, 1970. 
cza jego ideami polifoniczności i dialogiczności. Przypomnę, że polifonia (wielogłosowość) oznacza brak wyraźnego prymatu jednego głosu, wykluczenia nadrzędnej instancji i całkowitego podporządkowania, ostatecznej struktury prawdziwościowej. Dialogiczność z kolei zakłada, że słowo, wypowiedź lub dyskurs nie istnieją $w$ izolacji, zawsze są zapośredniczone, nawiązują do kontekstów wcześniej używanych, do innych słów, sytuacji, do innych użytkowników. Równie istotna jest filozoficzna myśl Chantal Mouffe ${ }^{17} \mathrm{i}$ jej opozycja między modelem agonicznym (przestrzeń publiczna jako miejsce walki niemożliwych do pogodzenia tożsamości hegemonicznych) a konsensualnym (zakłada możliwość zgody, choćby była to idea regulatywna). Bachtin i Mouffe kształtują podstawową siatkę wyobrażeń dialogicznych.

Dwa najistotniejsze kierunki z obszaru dialogicznych memory studies to $\mathrm{p} \mathrm{a}$ mięć wielokierunkowa i pamięć agonistyczna, które postaram się pokrótce przedstawić.

1. Pamięć wielokierunkowa Michaela Rothberga ${ }^{18}$ odrzuca wizję monologicznej, agresywnej pamięci o charakterze szowinistycznym i otwiera się na głos innego. Rothberg tworzy opozycję dwóch modeli społecznego funkcjonowania pamięci, wyróżnia pamięć wielokierunkową i rywalizującą:

Sprzeciwiając się uogólnieniu, w którym ujmuje się pamięć zbiorową jako pamięć rywalizującą - jako walkę o sumie zerowej toczącą się o niewystarczające zasoby - proponuję, byśmy uznali pamięć za zjawisko wielokierunkowe: za przedmiot nieustannych negocjacji, odesłań i zapożyczeń; za produktywną, a nie prywatywną. (s. 15)

Pamięć wielokierunkowa nie jest dana raz na zawsze, niezmienna - ma charakter relacyjny, wynika z wyborów i odróżnienia od innych pamięci. „Nie posiada własnego znaczenia, lecz zyskuje je w relacji z innymi wspomnieniami przez sieć skojarzeń" (s. 36).

Pamięć konstytuuje się przez decyzje. Tworzenie opowieści zawsze oznacza wybór: pomijamy jedne możliwości, wybieramy inne. Paradoksalnie w tej negacji owe niewybrane możliwości się uobecniają. Rothberg odrzuca popularny model pamięci, który zakłada jej izolację, jej nieporównywalność z żadną inną. Pamięć jako forma rywalizacji służy wykluczeniu i niszczeniu innych głosów, odmawianiu im prawa do istnienia. Charakterystycznym jej rysem jest współzawodnictwo $\mathrm{w}$ cierpieniu, tak dobrze znane również polskiemu doświadczeniu pamięci. Pamięć rywalizująca zakłada bowiem, że przestrzeń publiczna jest ograniczona.

${ }^{17}$ Chantal Mouffe, Agonistyka. Polityczne myślenie o świecie, tłum. Barbara Szelewa, Warszawa: Wydawnictwo Krytyki Politycznej, 2015.

${ }^{18}$ Michael Rothberg, Pamięć wielokierunkowa. Pamiętanie Zagłady w epoce dekolonizacji, tłum. Katarzyna Bojarska, Warszawa: Wydawnictwo IBL PAN, 2015. 
To w niej uprzednio umocowane grupy angażują się w walkę na śmierć i życie. W przeciwieństwie do tego ujęcia koncepcja wielokierunkowości pamięci zachęca nas do myślenia o przestrzeni publicznej jako elastycznej przestrzeni dyskursywnej, w której poszczególne grupy nie tyle wyrażają wcześniej sformułowane stanowiska, ile w zasadzie wytwarzają siebie przez dialogiczne interakcje $\mathrm{z}$ innymi; zarówno podmioty, jak i przestrzenie publiczne otwarte są na nieustające rekonstrukcje. (s. 19)

Proponowana przez Rothberga pamięć wielokierunkowa jest jej zaprzeczeniem, ma być nowym otwarciem, zakorzenia się w konkretnych aktach pamiętania oraz pojedynczych wytworach kultury, również w jej formach krytycznych. Sytuuje się na antypodach uogólnionej pamięci zbiorowej - niczyjej i abstrakcyjnej. Rothberg, wychodząc z założenia, że pamięć ma charakter relacyjny jest narracją wśród innych narracji i do nich się odnosi - dąży do „rozszczelnienia” wizji monologicznej, rozmontowania monogłosu. Pamięć w tym ujęciu jest zawsze zapośredniczona w innej, zawsze wielogłosowa, zawsze trochę swoja, a trochę cudza. Rekonstrukcja wspomnianego już punktu tworzenia pamięci pozwala znaleźć moment wyboru i pominięte, być może brane pod uwagę, możliwości, inne wersje pamięci. Pamięć wielokierunkowa może być dzięki temu szansą na nowe formy solidarności i sprawiedliwości.

Rothberg zauważa przy tym, że recepcja Zagłady wskazuje na ciekawą zależność. Pamięć o niej, jej wzmocnienie i odrodzenie splotły się w czasie z procesem dekolonizacji:

Pojawienie się pamięci nazistowskiego ludobójstwa w latach 50. i 60. XX w. pozostaje w dialogu z trwającymi wówczas procesami dekolonizacji i ruchem na rzecz praw obywatelskich. (s. 19)

Dekolonizacja i pamięć o traumie kolonizacji nie umniejsza pamięci Zagłady, przeciwnie, zasila je, wzmacnia i naświetla z innej perspektywy.

2. U NREST, czyli Unsettling Remembrance and Social Cohesion in Contemporary Europe Projekt (2016-2019), to ogromna międzynarodowa sieć badaczy $^{19}$. Kierują nią m.in. Ann Rigney, Peter Aronsson, Christopher Smith, Stefan Berger i Wulf Kansteiner. Już samo przyjrzenie się afiliacjom naukowym i dziedzinom zainteresowań wymienionych postaci pozwala się zorientować, jak bardzo interdyscyplinarny i zaangażowany jest to projekt. Główną płaszczyzną spotkania są właśnie memory studies. Projekt ma na celu opis i wydobycie pamięci wielogłosowej, a g o n i c znej, otwarcie nawiązuje do dziedzictwa Bachtina i Mouffe ${ }^{20}$. Zgodnie z jego założeniami pamięć agoniczna występuje

\footnotetext{
${ }^{19}$ Więcej na ten temat można znaleźć na stronie: http://www.unrest.eu/.

${ }^{20}$ Por. Stefan Berger, Agonistic memory is open-endedly dialogic in a Bakthinian sense, https://istorex.ru/Novaya_stranitsa_56?fbclid=IwAR0GwTeP7V032jnh3KItTtrFgxKMEgRHJSL8kiJZ0HokV4GefFj98k61gTk (dostęp 5 I 2021 r.).
} 
w podwójnej opozycji: raz wobec antag on is tycznej, drugi raz wobec pamięci kosmopolitycznej. Pamięć antagonistyczna jest charakteryzowana jako monologiczna, operuje przeciwstawieniem wróg-przyjaciel, dobro-zło, często cechuje ją ksenofobia, dąży do unicestwienia innych pamięci, do nacjonalistycznego wzmożenia, do wzmocnienia tożsamości, zmusza do jasnego zajęcia stanowiska i opowiedzenia się po którejś ze stron w konflikcie pamięci. Pamięć kosmopolityczna natomiast rodzi się z doświadczeń liberalizmu, odnosi się do praw człowieka i liberalnej demokracji. Pamięć kosmopolityczna może być $w$ punkcie wyjścia wielogłosowa i dialogiczna, ale ten dialog kończy się wraz $\mathrm{z}$ osiągnięciem konsensusu. Może również być wielojęzyczna, na plan pierwszy wysuwa ofiary konfliktów, współczuje im i pragnie je upamiętnić. Model ten jest zazwyczaj wiązany z koncepcjami Jürgena Habermasa i jego teorią racjonalności komunikacyjnej ${ }^{21}$.

Pamięć agoniczna z kolei to nieskończony dialog, który unika binaryzmów moralnych (dobro-zło) i kontekstualizuje przemoc. Pamięć agoniczna nie dąży do zatrzymania dialogu, wygładzenia różnic i pogodzenia sprzeczności. Jej ważnym tłem są badania komparatystyczne, porównujące lokalne doświadczenia pamięci, ale niezacierające istotnych różnic między nimi. Pamięć agonistyczna zatem nie poszukuje perspektywy wspólnej jako ostatecznego odniesienia narracji wyzutej z partykularyzmów, ale też nie zatrzymuje się na poziomie lokalnych uwarunkowań, zwłaszcza na poziomie narracji narodowej czy nacjonalistycznej, operuje na poziomie transnarodowym ${ }^{22}$. Pamięć taka unika moralnego wartościowania stron, przedstawia zaangażowane stanowiska jako część agonicznego konfliktu i traktuje jako równouprawnione, pod warunkiem że one same respektują pewne zasady i nie odmawiają stanowisku przeciwnemu prawa głosu.

Przedstawione koncepcje, czyli dialogiczne kierunki badań nad pamięcią, uważam za cenne i inspirujące. Ich próby otwarcia na wielorakość pamięci, na jej aspekt dialektyczny i komunikacyjny, są warte uznania i rozwinięcia. Równie ważne wydają mi się nieesencjalistyczne i społeczne podejście do pamięci, świadomość jej kontekstualności i uwarunkowań, nie dość często uświadamianych nie tylko w polskich badaniach nad pamięcią traumatyczną. Trzeba również docenić zaangażowanie tych kierunków - stanowią rodzaj interwencji i są wyrazem aktywnej postawy etycznej. Zarówno koncepcja wielokierunkowości, jak i koncepcja pamięci agonicznej sytuują się w centrum międzynarodowych rozważań nad pamięcią i mają wielu zwolenników w dziedzinie memory studies.

${ }^{21}$ Jürgen Habermas, Teoria działania komunikacyjnego, tłum. Andrzej Maciej Kaniowski. Warszawa: Wydawnictwo Naukowe PWN, 1999.

${ }^{22}$ Por. A Cultural History of Memory, t. 1-6, red. Stefan Berger, Jeffrey K. Olick, London: Bloomsbury Academic 2020. 
W Polsce koncept wielokierunkowości wydaje się jeszcze nie dość popularny ${ }^{23}$. Projekt sieci UNREST jest stosunkowo bardziej rozpowszechniony w naszym kraju, należą do niej także polscy badacze i badaczki, pracujący w międzynarodowych grupach.

Obie koncepcje nasuwają jednak wątpliwości i pytania. Przede wszystkim nie do końca wiadomo, na jakim poziomie teoretycznym operują. Czy wielokierunkowość i agonizm są opisem zalecanego podejścia naukowego, instrumentarium teoretycznym, które ma modelować dotychczasowe ustalenia i postawy teoretyczne? Wchodzą z nimi w polemikę? Znoszą dotychczasowe modele badań? Czy w myśl założeń Rothberga dialogiczność ma zastąpić dotychczasowe monologiczne podejścia jako nie dość trafne albo źle diagnozujące rzeczywistość? Czy też raczej dotyczą samej rzeczywistości, a więc pewnej realnej pracy pamięci, którą mylnie zwykło się uważać za antagonistyczną lub rywalizującą, podczas gdy w gruncie rzeczy pamięć działa w dialogu, jedna wywołuje i wzmacnia drugą, nie zabiera niczego innym i ich nie ogranicza? W pierwszym wypadku dotychczasowe podejścia byłyby błędem metodologicznym, $\mathrm{w}$ drugim zaś błędem poznawczym. Trudno się zgodzić z obydwiema tymi wykładniami. Pamięć antagonistyczna nie jest kwestią niewłaściwej interpretacji, fałszu poznawczego czy złego rozpoznania sytuacji, ale jest silnym, mocno osadzonym w kulturze i trwałym prądem, wobec którego podpowiadanie innych agonistycznych bądź wielokierunkowych możliwości może się okazać niewystarczające i wydaje się argumentem dość słabym ${ }^{24}$.

Aby uzmysłowić sobie, skąd bierze się mój opór wobec takiej konstelacji pojęć, proponuję poddać krótkiej analizie konkretny przykład. Rozważmy w duchu agonicznym Miejsce urodzenia, film Pawła Łozińskiego z 1992 r. Jest to, jak wiadomo, historia Henryka Grynberga, który poszukuje grobu swojego żydowskiego ojca, zamordowanego podczas wojny przez polskich współobywateli i pochowanego w niezidentyfikowanym miejscu. Bohater próbuje ustalić jego losy, przepytuje mieszkańców, w tym brata prawdopodobnego mordercy, a zarazem możliwego współsprawcy. Choć ostatecznie słyszymy/poznajemy nazwiska morderców i możemy zrekonstruować historię ukrywania się oraz zbrodni, a Grynberg lokalizuje grób ojca, większość wypowiedzi realizuje łatwo przewidywalną strategię: nie wiem, kto zamordował twojego ojca, to ktoś inny, obcy, nie ma dowodów, że zrobił to X, to już przeszłość i trzeba ją zostawić - mamy do czynienia z narracją wyparcia, zacierania śladów, z narracją sprawców. Głosy te nie negują potrzeby prawdy, wyrażają nawet poszukującemu prawdy współczucie (oprócz agresywnego syna sprawcy) ${ }^{25}$. Z perspektywy bachtinowskich dialogu-

\footnotetext{
${ }^{23}$ Mimo dość szybkiego przekładu książki Rothberga na język polski, który zawdzięczamy Katarzynie Bojarskiej.

${ }^{24}$ Warto również zauważyć, że pamięć antagonistyczna raczej wzmacnia się we współczesnym świecie i nie daje się wyciszyć.

${ }^{25}$ Głos sprawcy wcale nie unicestwia głosu ofiary.
} 
jących ze sobą głosów pamięci nie możemy tej narracji krytycznie prześwietlić i zanalizować, ponieważ ustanowilibyśmy głos finalny, oddzielilibyśmy prawdę od fałszu, zatrzymali nieskończony dialog, ustanowili opozycję dobro-zło.

To oczywiście uproszczona analiza, ale uświadamia nam, że agoniczne ujęcie pamięci bywa ślepe i nie pozwala odkryć gry władzy wokół dyskursów pamięciowych. I nie chodzi tu tylko o rozpoznanie prawdy i fałszu, dialogiczne ujęcie nie pozwala również zrekonstruować polityk pamięci, gdyż wszystkie głosy traktuje jako równorzędne, równosilne, obdarzone tą samą mocą retoryczną, dyskursywną i społeczną. Agonowi brak rozpoznania pola sił, nie rozróżnia dyskursu prawomocnego i napiętnowanego, ukrywającej narracji sprawców i narracji ofiar, nie widzi sfery społecznych podporządkowań ani roli polityki pamięci ${ }^{26}$ lub polityki historycznej. Agoniczna i wielokierunkowa koncepcja pomija realne stosunki władzy, zapoznaje to, że pamięć rozgrywa się w strukturze władzy, że charakteryzują ją stosunki panowania, a niekiedy przemocy, że uczestniczy $\mathrm{w}$ procesie tworzenia i potwierdzania tożsamości również pojmowanych jako wykluczające już u zarania, choć jako takie się nie przedstawiają. W tym sensie można kierunkom dialogicznym zarzucić ślepotę metodologiczną i niedostrzeganie istotnych gier $w$ polu pamięci.

\section{III}

Warto zwrócić uwagę na inny typ badań nad pamięcią, niezmiernie rzadki w memory studies zwłaszcza w Polsce. $\mathrm{Z}$ badaniami dialogicznymi łączy je wspólny punkt wyjścia, tj. założenie o kontekstualności i wielości pamięci, przeświadczenie, że pamięć kulturowa nie jest bytem wsobnym, lecz uwarunkowanym, zapośredniczonym przez czynniki społeczne i historyczne.

Podobnie jak projekt agoniczny i wielokierunkowy, nie jest to model uniwersalny, nie obejmuje całego pola badań nad pamięcią społeczną i kulturową, opisuje tylko niektóre jej fenomeny, nie dostarcza odpowiedzi na pytanie, czym jest pamięć. Jego zaletą jest natomiast zwrócenie uwagi na rzadko analizowane aspekty pamięci społecznej. Chciałabym mianowicie zaproponować analizę klasową pamięci społecznej. Badanie to rodzi silny opór w polskim świecie naukowym ze względu na główną kategorię ${ }^{27}$, uważaną za skompromitowaną jako

${ }^{26}$ Terminy te mają obszerną literaturę przedmiotu. Więcej na temat mojego rozumienia polityki pamięci można znaleźć w moim szkicu Uprawomocnienie komunizmu. Budować i burzyć, w: Komunizm. Idee i praktyki w Polsce 1944-1989, red. Katarzyna Chmielewska, Agnieszka Mrozik, Grzegorz Wołowiec, Warszawa: Wydawnictwo IBL PAN, 2018 (seria „Komunizm. Idee - Dyskursy - Praktyki”), s. 22-62. W największym skrócie: przez politykę pamięci rozumiem władzę modelowania narracji o przeszłości, jej specyficznego fabularyzowania przez czynniki społeczne i tożsamościowe. Polityka historyczna to uprawianie polityki pamięci na poziomie instytucji państwowych.

${ }^{27}$ Jerzy Kochan, Studia z teorii klas społecznych, Warszawa: Wydawnictwo Naukowe Scholar, 2011. 
termin niegdysiejszego oficjalnego marksizmu ${ }^{28}$. Rzeczywiście mówienie o klasie stało się tabu (zresztą nie tylko w Polsce) i uchodzi za naruszenie naukowego decorum $^{29}$. Trzeba jednak przypomnieć, że jest to podstawowa kategoria socjologiczna i używał jej nie tylko Karol Marks, lecz także Max Weber.

Znaczenie słowa „klasa” zapożyczam od Pierre’a Bourdieu ${ }^{30}$. Odnosi się ono zatem do kapitału symbolicznego, społecznego i kulturowego oraz do habitusu, nie zaś miejsca w stosunkach produkcji (jak u Marksa). W tym kontekście uznaję, że habitus to trwałe dyspozycje, mające źródła w położeniu społecznym, dyspozycje, które kształtują się w społecznych interakcjach uczenia się, nabywania kompetencji, a objawiają w specyficznym postrzeganiu świata, wartościowaniu (również nieświadomym), regułach uważanych za niepodważalne. Habitus określa trajektorie życia, aspiracje zawodowe, towarzyskie, ekonomiczne, społeczne, kwestię gustu, możliwe do wyobrażenia opcje przyszłości i decyzje życiowe. „Koncepcja klas polega na dokonaniu teoretycznego połączenia aktorów, którzy, będąc przedmiotem podobnych warunków, mają tendencję do upodabniania się do siebie, a wskutek tego skłonność do łączenia się praktycznego, do łączenia się w praktyczną grupę, a tym samym do wzmacniania swoich wzajemnych podobieństw"31. Owe podobieństwa są nicią rozpoznawalnej wspólnoty wyobrażonej. Scharakteryzowana w ten sposób klasa ma charakter antagonistyczny względem innych grup. Klasy średnie i wyższe konstytuują się w opozycji do klas ludowych na mocy władzy produkowania dyskursu prawomocnego, w szczególności zaś prawomocnej władzy sądzenia, prawomocnego gustu oraz poczucia wyższości moralnej. Pamięć kulturowa i społeczna jest ważnym elementem owej przewagi symbolicznej, miejscem, w którym również ona się realizuje.

Inteligencja ${ }^{32}$ - i szerzej mieszczaństwo lub inaczej mówiąc klasa średnia produkuje zatem prawomocną pamięć, narzucając na mocy swojej symbolicznej przewagi interpretację przeszłości grupom podporządkowanym, nieznajdującym własnej reprezentacji symbolicznej lub niepotrafiącym jej nadać mocy zobowiązującej. Klasowa analiza tego zjawiska pozwala odsłonić szczególne mechanizmy polityki pamięci, czyli tworzenia ram narracyjnych, reguł dyskursu, które będą respektować poszczególne opowieści.

${ }^{28}$ Włodzimierz Wesołowski, Klasy, warstwy i władza, Warszawa: Wydawnictwo Naukowe PWN, 1997.

${ }^{29}$ Robert Brubaker, Ethnicity without Groups, Cambridge, MA: Harvard University Press, 2004.

${ }^{30}$ Pierre Bourdieu, Dystynkcja. Społeczna krytyka władzy sądzenia, tłum. Piotr Biłos, Warszawa: Wydawnictwo Naukowe Scholar, 2005.

${ }^{31}$ Pierre Bourdieu, Co tworzy klasę społeczną? O teoretycznym i praktycznym istnieniu grup, tłum. Jakub Maciejczyk. „Recycling Idei” 2008, nr 11, s. 39.

${ }^{32}$ Pozostawiam na boku jałową moim zdaniem dyskusję, czy inteligencja jest klasą czy warstwą społeczną, i ze względu na jej antagonistyczny charakter traktuję ją jako klasę. Z podobnych powodów nie podejmuję dyskusji, czy współczesna inteligencja nadal ma przewagę symboliczną i stanowi klasę. 
Posłużę się szczególnym przykładem. Mam na myśli pamięć o Zagładzie w Polsce i sporo jej ukrytych, klasowych przejawów. Względnej widzialności chłopskiego wydawania Żydów, ich mordowania i grabienia towarzyszy niewidzialność inteligencji i jej kluczowej roli w produkowaniu antysemityzmu, reprodukowaniu wykluczenia i wzorów antysemickich poprzedzających Zagładę $^{33}$. To inteligencja tworzyła i produkowała przed wojną antysemicką kulturę, prasę, książki, instytucje, urządzenia społeczne, prawo, ze szczególnym uwzględnieniem numerus clausus. Antysemityzm kadr naukowych i studentów był wzorem akceptowanym, getto ławkowe i nieustanne domaganie się numerus nullus, wreszcie wykluczanie Żydów ze związków i stowarzyszeń twórczych te oczywiste fakty są notorycznie prześlepiane. To właśnie antysemickie wzory umożliwiły bezpośrednie zaangażowanie w $\mathrm{Szoa}^{34}$.

Inteligencja wyparła jednak z obrazu Zagłady własny w niej udział ${ }^{35}$. Pamiętajmy, że oprócz ubrań, butów, pieniędzy i kosztowności kradziono kamienice, mieszkania, niewielkie zakłady pracy, przejmowano kancelarie adwokackie, praktyki medyczne itd. Nie była to działalność chłopów ani robotników, ale polskich mieszczan i inteligencji. We współczesnej, a nawet w tużpowojennej pamięci społecznej wszystkie te fakty ulatują ${ }^{36}$, na scenie pozostają chłopi, inteligencja zaś tonie w mroku niepoznania.

Warto przyjrzeć się mechanizmom aktywnego kształtowania pamięci zbiorowej, które polegają na przenoszeniu, przesuwaniu i rozpraszaniu obrazów przeszłości. Zmiany te są rezultatem działania aktywnych bądź reaktywnych sił, które korzystając z różnicy kapitału kulturowego i symbolicznego ${ }^{37}$, dokonują przesunięć, nie tylko zresztą w polu przeszłości, lecz także w polu teraźniej-

${ }^{33}$ Więcej na ten temat piszę w szkicu The Intelligentsia and the Holocaust. Dispersing the Image („Studia Litteraria et Historica” 2018, nr 7, https://doi.org/10.11649/slh.1704).

${ }^{34}$ Przy okazji warto wspomnieć o kwestii zasadniczej, tj. wpływie religii chrześcijańskiej i kleru na kształtowanie wyobrażeń i postaw antysemickich zarówno wśród inteligencji, jak i chłopów. Czy kler to inteligencja? Pozostawiam to pytanie bez odpowiedzi, uważam bowiem, że to obszerny temat na osobny tekst.

${ }^{35}$ Kiedy używam słowa „wyparła”, świadomie unikam zwrotów biernych, a mianowicie że pamięć została wyparta czy zatarta. Prawomocny przekaz o Zagładzie, tak jak cały prawomocny przekaz o przeszłości, pozostaje w gestii inteligencji, to ona pisze książki, robi filmy, projektuje wystawy itp. Nie znaczy to oczywiście, że głos ten jest jednobrzmiący, mówię tylko o narracji dominującej.

${ }^{36}$ Tworzenie figury świadka Zagłady, świadka moralnego, który w gruncie rzeczy usuwa w cień własne zaangażowanie i tworzy mit lepszości inteligencji w porównaniu z resztą społeczeństwa, rozpoczyna się już w latach czterdziestych. Więcej na ten temat w moim szkicu Konstruowanie figury polskiego świadka podczas Zagłady [w:] Opowieść o niewinności. Kategoria świadka Zagłady w kulturze polskiej (1942-2015), red. Maryla Hopfinger, Tomasz Żukowski, Warszawa: Wydawnictwo IBL PAN, 2018, s. 53-98.

${ }^{37}$ Bourdieu, Dystynkcja. Społeczna krytyka władzy sądzenia... 
szości. To szczególna postać wyparcia, ponieważ, trzeba to mocno podkreślić, nie ma ono nic wspólnego z traumą ani z psychoanalitycznym arsenałem pojęć i wyobrażeń. To nie trauma każe odsuwać odpowiedzialność od siebie samych. Działanie to okazuje się skuteczne ze względu na przewagę kapitału symbolicznego, który pozwala zjawiska z przeszłości uczynić widzialnymi (lub nie), może zatrzeć obrazy, uczynić elementami tak oczywistymi, że słabo rozpoznanymi, niełączącymi się w żadną całość.

Niekiedy w dyskursie publicznym dochodzi do jeszcze mocniejszych przesunięć. Inteligencja nie tyle pozostaje w mroku, ile traktuje siebie jako przeciwwagę dla zbrodniczych i morderczych chłopów, portretując się jako dobrotliwy, ale słaby pan, który z powodu wywołanego wojną kryzysu autorytetów nie znalazł w sobie dość sił, aby powstrzymać zło. Inteligencja miałaby zatem stanowić moralną i faktyczną barierę dla wykluczenia, grabienia i mordowania. Tę strategię przypisywania sobie wyższości moralnej i estetycznej można rozpoznać jako klasyczny topos przewagi symbolicznej. Taka strategia immunizacyjna daje o sobie znać wielokrotnie. W tekście publicystycznym uznanego historyka społecznego czytamy na przykład:

Jednocześnie w ramach akcji AB Niemcy przeprowadzili masowe aresztowania wśród inteligencji. [...] W ten sposób $\mathrm{w}$ wojennych migracjach i eksterminacjach, na polach bitew zginęła Polska A: wykształcona, opiniotwórcza, urzędnicza, której bliskie były wartości i symbole II Rzeczpospolitej. Dziś powiedzielibyśmy: klasa średnia, podstawa stabilności ładu społecznego. Jej brak należy dopisać do genezy chłopskiego mordowania obcych ${ }^{38}$.

Z dalszej części tekstu dowiadujemy się, że owi mordujący, którzy „nie wsiedli do pociągu modernizacji", nie mają nawet światopoglądu, najwyżej ograniczony świat wyobrażeń, przeświadczenie, że aby mieć, trzeba ukraść. Są całkowicie obcy, toteż trzeba etnograficznej egzegezy, by zrozumieć, jak ich świat się układa, zupełnie inaczej niż „dla nas, przesiąkniętych purytańską ascezą głoszącą związek między pracą a bogaceniem się". Ów paternalistyczny ton, z gruntu fałszywie ukazujący rolę inteligencji, pomijający realia historyczne, nie jest zjawiskiem odosobnionym, ale stanowi najbardziej rozpowszechniony dyskurs, pozwalający inteligencji nie tylko uniknąć oskarżenia o antysemityzm i zaangażowanie podczas Szoa, ale z góry sytuujący ją na biegunie pomocy Żydom.

Opowieść inteligencji o sobie samej skrywa jej rolę, zniekształca obraz przeszłości, rozmywając konkrety i realia, by narzucić pochlebną wizję strażnika moralności, który opowiada się po właściwej stronie, daje świadectwo. Moralistyczne wzmożenie, korzystanie z mocy autorytetu w zacieraniu przeszłości i wskazywaniu innych jako wyłącznych sprawców świadczą o przemocy symbolicznej, a także pozwalają mówić o polityce pamięci „rozrzedzonej” - obywającej się bez zwartych instytucji, nie podporządkowanej potrzebom jednej kampanii,

\footnotetext{
${ }^{38}$ Marcin Zaremba, O polskiej banalności zła, „Polityka” 2011, nr 12.
} 
nie prowadzonej przez jeden rozpoznawalny i jasno ograniczony podmiot, ale rozciągającej się w czasie; o trwałej formie kształtowania ram dyskursu publicznego, tak by nie odsyłał on bezpośrednio do władzy politycznej, rządu, ministerstwa, jakiejkolwiek agendy, ale odnosił się do inteligenckiego habitusu. Ramy te określają nie tylko warunki przedstawiania przeszłości, decydują nie tylko o prezentowanych lub pominiętych treściach, lecz także formują podmioty inteligenckie w taki sposób, że jedynie z dużym oporem, niejako przekraczając swoją kondycję kulturową, mogą się zdobyć na wysiłek krytycznej analizy własnych praktyk.

Postawmy sprawę jasno, istotnie część, a nawet z pewnością większość ukrywających się Żydów-ofiar została obrabowana i pozbawiona życia przez chłopów, ale nie tylko chłopów, i to metonimiczne przesunięcie służy oczyszczeniu się inteligencji z zarzutu antysemityzmu, uniknięciu odpowiedzi na pytanie o jej rolę podczas Zagłady. Inteligencja nie kieruje światła we własną stronę, nie mówi pro domo sua, lecz wyłącznie o chłopach, których z racji różnicy kapitałów symbolicznych łatwo uczynić jedynymi winowajcami. Inteligencja rozmywa własny obraz z przeszłości i pozwala, by w tym miejscu pojawił się podmiot chłopski samotnie. Przerzucenie całego odium antysemityzmu na chłopów, wyparcie obrazu inteligencji produkującej wykluczenie i nienawiść rasową skutkuje wciąż powtarzającą się błędną tezą, a właściwie alibi - antysemityzm to ciemnota, brak i niedostatek kultury, chamstwo, nie zaś trwały wzór kulturowy. Antysemityzm to nie my, ludzie kulturalni - to oni, wstrętni, nieokrzesani „inni”, którzy nie mają z nami nic wspólnego.

W tej klasowo uwarunkowanej polityce pamięci, obecnej od lat czterdziestych aż po współczesność być może pobrzmiewają dialogicznie głosy cudze, ale opis tych głosów jako współobecnych byłby wypaczeniem ich rzeczywistego funkcjonowania. Zjawisko dominacji trudno bowiem przedstawić adekwatnie przy użyciu kategorii agonu czy wielokierunkowości, ponieważ prowadziłoby to do głębokiej dezinterpretacji nakreślonego przeze mnie w największym skrócie fenomenu. Narzędzia analizy habitusu klasowego pozwalają natomiast uchwycić i opisać realne funkcjonowanie pamięci o Zagładzie w Polsce w jej słabo rozpoznanych przejawach.

\section{BIBLIOGRAFIA}

Ankersmith Frank, Historical Representation, Stanford, CA: Stanford University Press, 2001.

Ankersmith Frank, Political Representation, Stanford, CA: Stanford University Press, 2002.

Assmann Aleida, Assmann Jan, Schrift und Gedächtnis: Beiträge zur Archäologie der literarischen Kommunikation, München: Fink, 1987.

Assmann Aleida, Memory, Individual and Collective [w:] The Oxford Handbook of Contextual Political Analysis, red. Robert E. Goodin, Charles Tilly, Oxford: Oxford University Press, 2006. 
Assmann Aleida, Vier Grundtypen der Zeugenschaft [w:] Zeugenschaft des Holocaust. Zwischen Trauma, Tradierung und Ermittlung, red. Michael Elm, Gottfried Kößler, Frankfurt am Main-New York: Campus, 2007.

Bachtin Michaił, Problemy poetyki Dostojewskiego, tłum. Natalia Modzelewska. Warszawa: PIW, 1970.

Bachtin Mikhail, Problems of Dostoevsky’s Poetics, tłum. Caryl Emerson. Minneapolis: University of Minnesota Press, 1984.

Berger Stefan, Agonistic memory is open-endedly dialogic in a Bakthinian sense, https:// istorex.ru/Novaya_stranitsa_56?fbclid=IwAR0GwTeP7V032jnh3KItTtrFgxKMEgRHJSL8kiJZ0HokV4GefFj98k61gTk.

Bourdieu Pierre, Co tworzy klasę społeczna?? O teoretycznym i praktycznym istnieniu grup, tłum. Jakub Maciejczyk. „Recycling Idei” 2008, nr 11, s. 39.

Bourdieu Pierre, Dystynkcja. Społeczna krytyka władzy sądzenia, tłum. Piotr Biłos, Warszawa: Wydawnictwo Naukowe Scholar, 2005.

Brubaker Rogers, Ethnicity without Groups, Cambridge, MA: Harvard University Press, 2004.

Cento Bull Anna, Hansen Hans Lauge, Agonistic Memory and the UNREST Project, „Modern Languages Open", 2020, nr 1, http://doi.org/10.3828/mlo.v0i0.319, https:// www.modernlanguagesopen.org/articles/10.3828/mlo.v0i0.319/.

Chmielewska Katarzyna, Konstruowanie figury polskiego świadka podczas Zagłady [w:] Opowieść o niewinności. Kategoria świadka Zagłady w kulturze polskiej (19422015), red. Maryla Hopfinger, Tomasz Żukowski, Warszawa: Wydawnictwo IBL PAN, 2018.

Chmielewska Katarzyna, The Intelligentsia and the Holocaust. Dispersing the Image, „Studia Litteraria et Historica” 2018, nr 7, https://doi.org/10.11649/slh.1704.

Chmielewska Katarzyna, Uprawomocnienie komunizmu. Budować i burzyć [w:] Komunizm. Idee i praktyki w Polsce 1944-1989, red. Katarzyna Chmielewska, Agnieszka Mrozik, Grzegorz Wołowiec, Warszawa: Wydawnictwo IBL PAN, 2018.

A Cultural History of Memory, t. 1-6, red. Stefan Berger, Jeffrey K. Olick, London: Bloomsbury Academic, 2020.

Cultural Memory Studies. An International and Interdisciplinary Handbook, red. Astrid Erll, Ansgar Nünning, Berlin: De Gruyter, 2008.

Domańska Ewa, Historia egzystencjalna. Krytyczne studium narratywizmu i humanistyki zaangażowanej, Warszawa: Wydawnictwo Naukowe PWN, 2012.

Domańska Ewa, Nekros. Wprowadzenie do ontologii martwego ciała, Warszawa: Wydawnictwo Naukowe PWN, 2017.

Habermas Jürgen, Teoria działania komunikacyjnego, tłum. Andrzej Maciej Kaniowski, Warszawa: Wydawnictwo Naukowe PWN, 1999.

Historia - dziś. Teoretyczne problemy wiedzy o przeszłości, red. Ewa Domańska, Rafał Stobiecki, Tomasz Wiślicz, Kraków: Universitas, 2014.

History of Oral History: Foundations and Methodology, red. Thomas L. Charlton, Lois E. Myers, Rebecca Sharpless, Lanham: Alta Mira Press, 2007.

Historyk wobec źródeł. Historiografia klasyczna i nowe propozycje metodologiczne, red. Joanna Kolbuszewska, Rafał Stobiecki, Łódź-Kurowice: Wydawnictwo Naukowe Ibidem, 2010.

Kochan Jerzy, Studia z teorii klas społecznych, Warszawa: Wydawnictwo Naukowe Scholar, 2011.

Memory and Political Change, red. Aleida Assmann, Linda Shortt, London: Palgrave Macmillan, 2011. 
Mouffe Chantal, Agonistyka. Polityczne myślenie o świecie, tłum. Barbara Szelewa. Warszawa: Wydawnictwo Krytyki Politycznej, 2015.

Nijakowski Lech M., Polska polityka pamięci. Esej socjologiczny, Warszawa: Wydawnictwa Akademickie i Profesjonalne, 2008.

Nora Pierre, Between Memory and History: Les Lieux de Mémoire, „Representations” 1989, t. 26, https://doi:10.1525/rep.1989.26.1.99p0274v.

Pamięć i polityka historyczna. Doświadczenia Polski i jej sq̨siadów, red. Sławomir M. Nowinowski, Jan Pomorski, Rafał Stobiecki, Łódź: Wydawnictwo Naukowe Ibidem, 2008.

Rothberg Michael, Pamięć wielokierunkowa. Pamiętanie Zagłady w epoce dekolonizacji, tłum. Katarzyna Bojarska, Warszawa: Wydawnictwo IBL PAN, 2015.

Sendyka Roma, Pryzma - zrozumieć nie-miejsca pamięci (non-lieux de memoire), „Teksty Drugie" 2013, nr 1/2.

Stobiecki Rafał, Historycy polscy wobec wyzwań XX wieku. Poznań: Wydawnictwo Nauka i Innowacje, 2014.

Thompson Edward P., History from Below, „Times Literary Supplement”, 7 IV 1966.

Tokarska-Bakir Joanna, Pod klątwą. Społeczny obraz pogromu kieleckiego, t. 1-2, Warszawa: Czarna Owca, 2018.

Welzer Harald, Das kommunikative Gedächtnis. Eine Theorie der Erinnerung, München: Beck, 2011.

Welzer Harald, Sabine Moller, Karoline Tschuggnall, „Dziadek nie był nazistą”. Narodowy socjalizm i Holokaust w pamięci rodzinnej, tłum. Paweł Masłowski [w:] Pamięć zbiorowa i kulturowa. Współczesna perspektywa niemiecka, red. Magdalena Saryusz-Wolska, Kraków: Universitas, 2009.

Wesołowski Włodzimierz, Klasy, warstwy i władza, Warszawa: Wydawnictwo Naukowe PWN, 1997.

Zaremba Marcin, O polskiej banalności zła, „Polityka” 2011, nr 12. 